\title{
FACULTY ROLES AND ROLE PREFERENCES IN TEN FIELDS OF PROFESSIONAL STUDY
}

\author{
Joan S. Stark, Malcolm A. Lowther, and Bonnie M. K. Hagerty
}

Teaching faculty in ten entry-level professional fields reported varying amounts of time devoted to teaching, research, consulting, and professional practice but did not differ in time devoted to administration. The faculty member's own role view was most closely related to time use, but for time spent in teaching and research, faculty age and institutional type (but not gender) were also significant predictors. Even after several general demographic characteristics and environmental variables that potentially differentiate professional from discipline-based faculty are taken into account, different professional fields may be characterized by group climates which influence or reinforce certain faculty roles.

During the last twenty-five years, studies of how faculty members view and perform various academic roles have become increasingly common. Recently, several reviewers have synthesized this growing empirical literature. Most have focused on the research role (Finkelstein, 1984; Fox, 1985; Creswell, 1985), but some have been concerned with teaching and consulting roles as well (Lewis and Becker, 1979; Doyle, 1983; Finkelstein, 1984; Boyer and Lewis, 1985).

In one review, Fox (1985) discusses three sets of potential predictors of scholarly productivity: (1) personal and demographic characteristics; (2) aspects of the work environment; and (3) reward and reinforcement systems. Although Fox has focused on the research role, these sets of predictors constitute the major variables present in most work settings. Therefore, their predictive value also may be examined in relation to faculty teaching and service roles.

Joan S. Stark, Center for the Study of Higher and Postsecondary Education, 2002 School of Education, The University of Michigan, Ann Arbor, MI 48109. Malcolm A. Lowther and Bonnie M. K. Hagerty, School of Education, The University of Michigan.

\section{Research in Higher Education \\ (c) 1986 Agathon Press, Inc. \\ Vol. 25 , No. 1}


While distinguishing among these three groups of predictors for purposes of discussion, Fox stresses their interrelationships. For example, personal characteristics are mediated by the social and organizational context, the work environment may be associated with disciplinary reinforcement systems, and the salience of reinforcers is related to both the psychological characteristics of academics and the social context of their work. In concluding her review, Fox suggests fine tuning of studies to more fully understand faculty role performance and its correlates. Specifically, she suggests attention to "group climate" (p. 271) and indicates that in devising and implementing reward systems "administrators must be careful to avoid single standards of productivity across disciplines" (p. 275).

The academic disciplines are one determinant of group climate that has been an important covariate in studies of faculty role. The disciplinary group has been viewed as an important source of reinforcement for faculty. It is clear, for example, that norms in some fields support publication of articles, while in other fields books are more highly valued. Similarly, fields that demonstrate consensus regarding a research paradigm have been found to exert stronger normative publishing pressures on faculty than those which lack consensus (Fox, 1985, p. 256; Creswell, 1985, p. 42).

Strikingly, the studies summarized by Fox (see also Creswell, 1985, pp. 22-23) discuss potential variation among academic disciplines but omit consideration of faculty members in applied professional fields. Studies of faculty roles typically have included academics in chemistry, physics, biology, economics, sociology, political science, and psychology. Occasionally, a study includes faculty members in education or engineering (e.g., Tuckman and Hagemann, 1976). On the whole, however, when professional program faculty are mentioned, investigators seem to assume they are a homogeneous group. To illustrate, Finkelstein (1984) speculates about how faculty members in "the new professions" and the "semi-professions" might differ from those in the disciplines. In doing so, he cites the rapid and continuing growth of this segment of the faculty.

Although growth in faculty numbers has lagged behind student enrollments, more than $50 \%$ of all college students are now enrolled in professional fields such as education, nursing, engineering, architecture, business, journalism, various health professions, and others. As roles of faculty in such professional programs are examined, studies about faculty role performance may require not only fine tuning, but currently accepted generalizations may require major modifications. Informed observations suggest that professional faculty differ from disciplinary faculty, and from each other, in each of the three categories of faculty role predictors discussed by Fox. Some examples of such differences follow.

Among personal characteristics, researchers have found some declines in 
faculty research productivity with age. Some have suggested that the relation between age and publication is nonlinear, with peak activity about ten years after graduate school and again after age fifty. Such studies usually assume that faculty members begin academic careers in their late twenties or early thirties directly after sequential completion of undergraduate and graduate education. As Finkelstein (1984, pp. 45-49) points out, however, faculty members make two relatively independent career choices: the choice of a field and the choice of entering the academic position. In professional fields, the timing of these choices differs considerably from that in the academic disciplines. For professional faculty, graduate school may follow a period of professional practice. Because of this difference, the related assertion by investigators that lifelong research productivity is strongly predicted by publishing one's first article before or promptly after graduate school may also be suspect. The first article could be published at age forty-five to fifty for some professional field academics, nearly coincident with the period of impending decline or the "second peak" hypothesized for those in traditional disciplines. Since the relationship between age, career development, and scholarly activity remains largely unexamined for professional faculty, the extent of such deviations from patterns demonstrated by the traditional disciplines is unknown.

Among environmental factors, the period of doctoral study is frequently described as a strong socializing force and cultivator of academic norms. Apparently referring to doctoral study in the disciplines, Fox asserts that "Graduate education shapes conceptions of the scholarly role, styles of work and standards of performance. In fact, most academics do not alter their ideas and approaches after graduate school" (p. 264). Since faculty members in fields such as nursing, social work, and architecture may possess a professional master's, rather than a doctorate, as their highest degree, we might anticipate different socializing forces to be at work. In such fields, for example, the professional practice setting may constitute an initial socializing force which continues to be influential.

Finally, in the category of reinforcement and rewards, strong evidence points to collegial groups of scholars as important reference groups for discipline-based faculty members. Arguably, in some professional fields, practitioner colleagues as well as scholarly colleagues may provide reinforcement for faculty work. For such faculty, both reference groups may comprise the faculty members" "colleague climate" (Finkelstein, 1984, p. 97) and may provide reinforcing or conflicting norms.

Although the above observations relate to Fox's analysis of factors already identified as predictors of researeh productivity, parallel discussions could stress ways in which the teaching and service roles of faculty in diverse professional fields might differ from those in the disciplines. Finkelstein 
(1984, pp. 8-29) discusses an earlier conception viewing faculty members' careers as having three facets: a disciplinary career, an institutional career, and an external career of work-related activities external to the institution (Light, Marsden, and Corl, 1972). Whereas it may be true for disciplinebased faculty that career advancement depends upon interaction of only two of these subsystems, the disciplinary association and the stratification systems of institutions (Finkelstein, 1984, pp. 60-61), possibly the third subsystem, the externally based practitioner/service association, is also salient for faculty in some applied fields.

\section{PURPOSE OF THE STUDY}

For a diverse set of professional field faculty members, this study explored relationships among some of the variables other investigators have identified as potential predictors of faculty roles and role performance. Elaborating on Fox's categorization, it also considered several demographic, environmental, and reinforcing predictors that may be unique to the roles of faculty teaching in various professional fields of study. Specifically, this survey-based correlational study sought to determine whether the way faculty members distribute their time among teaching, research, and other activities is associated with such variables as (1) experience as a professional practitioner; (2) possession of a doctoral degree rather than a master's degree; (3) the faculty member's own role view; (4) the faculty member's espoused ideology of professional education; (5) the faculty member's perceived view of professional community influences; and (6) the particular professional field.

The comparative analysis included 1,294 faculty members without administrative titles who teach primarily in entry level programs in one of ten professional fields: architecture, business administration (undergraduate), teacher education, engineering, journalism, law, library science (master's programs), nursing, pharmacy, and social work (both bachelor's and master's levels). The dependent variables were the percentages of time faculty members reported devoting to five roles: (1) teaching; (2) research; (3) professional practice; (4) consulting; and (5) administrative activities. The following questions were posed.

1. Are there significant differences among the ten professional fields in the way faculty members report distributing their time across several faculty roles?

2. Do the bivariate correlation patterns between demographic, environmental, and reinforcer variables hypothesized as especially relevant to professional field faculty suggest that these variables may influence faculty time usage?

3. After known predictors of faculty time usage such as age, gender, and 
institutional type have been taken into account in a multivariate analysis, are other predictors associated with time usage for professional faculty?

\section{METHOD}

\section{Data Source}

Data came from a 1985 survey of a national population of faculty in the 551 most comprehensive colleges and universities (Carnegie Classifications-Research Universities, Doctoral Universities, and Comprehensive Colleges and Universities I). The sampling unit was the program, and the population included 1,814 professional programs whose existence was confirmed by college registrars through a mail inquiry. Although no known data source indicates the precise number of both accredited and nonaccredited programs or the number of faculty in each field, we estimate that our study population included approximately $70 \%$ of all existing programs in the ten professional fields (Stark, Lowther, and Hagerty, 1986b).

The survey sample of programs was selected from a sampling frame stratified by Carnegie Classification, type of control (public or independent), and expected enrollment decline ${ }^{1}$ in the state where the institution is located. For fields with less than 125 programs in the confirmed national population, all programs were surveyed; for the more commonly offered programs, a $50 \%$ random sample was drawn from each stratification cell. Surveys were distributed through program administrators (deans or department chairpersons), who were asked to respond to the survey and to request responses from faculty who, in their judgment, were most closely involved in and knowledgeable about the preservice professional preparation program. The number of full-time faculty responses requested was proportional to the annual number of program graduates supplied by the college registrar. Since student/faculty ratios varied considerably across fields, different ratios were used for different fields to result in approximately 4.65 responses for the program of mean size in each study field. The sample was intended to represent the variety of existing programs within each field. Since the proportionality constants relating faculty sample size to the annual number of graduates differed by field, it is appropriate to compare faculty responses from each field with those from each of the other fields, but it is not appropriate to report measures of central tendency for the entire set of respondents.

A total of 2,217 timely and usable faculty responses from 732 programs in 346 different colleges and universities was obtained after two follow-ups. This represented an overall response rate of $69.8 \%$ of the programs from which responses were requested and of $46 \%$ of the desired faculty sample. Program response rate varied from $56 \%$ for architecture to over $95 \%$ for 
master's level programs in library science and social work. Faculty response rates varied from $31 \%$ for architecture to $62 \%$ in nursing and library science. The respondent sample was unbiased with respect to the stratification parameters used to construct the sampling frame. The nature of possible bias due to distribution by deans and chairpersons to selected faculty is unknown.

Although deans, chairpersons, and faculty members completed the survey, this analysis includes only faculty members who reported holding no administrative role or who were program coordinators, an assignment assumed to carry less administrative responsibility than department chairperson. After excluding deans, assistant and associate deans, department chairpersons, and those reporting other administrative titles, the total analysis sample was comprised of 1,294 teaching faculty in the ten professional programs. Table 1 reports the number of teaching faculty from each professional field included in the analysis along with the enrollment characteristics of the varied institutional settings from which they were drawn.

\section{Description of Variables and Method of Analysis}

Hierarchical multiple regression was used to answer the primary research question:

After known predictors of faculty time usage such as age, gender and institutional type have been taken into account, are other predictors associated with time usage for professional faculty?

Thus, the analysis proceeded by comparing across the ten professional fields the distributions and intercorrelations of five dependent variables, namely, faculty self-reports of the percentage of working time they devoted to: (1) teaching; (2) research; (3) professional practice; (4) consulting; and (5) administrative tasks. Next, the distributions and correlation patterns among the selected independent variables and between the independent and dependent variables were examined. Finally, five separate regressions were conducted, each of which tested whether, after accounting for fixed demographic variables, prediction of time use improved by adding environmental and reinforcement variables suggested by previous research and believed especially appropriate to the backgrounds and roles of professional faculty. The rationale and metrics for the derivation of each dependent and independent variable are described prior to reporting study results.

It should be noted that no theory ensures that faculty time usage is the appropriate dependent variable or that the other variables used as predictors are causative. Since environmental conditions and reward systems (including externally imposed work assignments in some colleges) may reinforce behav- 
TABLE 1. Institutional Characteristics of Survey Respondents

\begin{tabular}{|c|c|c|c|c|c|c|c|}
\hline \multirow{2}{*}{$\begin{array}{l}\text { Professional } \\
\text { Program and } \\
\text { Institutional } \\
\text { Type }\end{array}$} & \multirow{2}{*}{$\begin{array}{c}\text { Programs } \\
\text { Responding }\end{array}$} & \multirow{2}{*}{$\begin{array}{l}\text { Percentage } \\
\text { Response }\end{array}$} & \multirow{2}{*}{$\begin{array}{l}\text { No. of } \\
\text { Faculty } \\
\text { in } \\
\text { Analysis }\end{array}$} & \multicolumn{2}{|c|}{$\begin{array}{l}\text { Institutional } \\
\text { Enroliment }\end{array}$} & \multicolumn{2}{|c|}{$\begin{array}{c}\text { Number of } \\
\text { Annual Program } \\
\text { Graduates }\end{array}$} \\
\hline & & & & Range & Mean & Range & Mean \\
\hline Architecture & 36 & 56.3 & 58 & $2,851-34,468$ & 17,686 & $4-300$ & 93 \\
\hline Public Research & 15 & & 26 & & & & \\
\hline Ind. Research & 6 & & 7 & & & & \\
\hline Public Doctoral & 6 & & 7 & & & & \\
\hline Ind. Doctoral & 1 & & 2 & & & & \\
\hline Public Comp. I & 5 & & 9 & & & & \\
\hline Ind. Comp. I & 3 & & 7 & & & & \\
\hline Business Adm. & 102 & 57.6 & 137 & $1,477-34,914$ & 12,950 & $17-1,299$ & 414 \\
\hline Public Research & 13 & & 28 & & & & \\
\hline Ind. Research & 5 & & 7 & & & & \\
\hline Public Doctoral & 15 & & 18 & & & & \\
\hline Ind. Doctoral & 6 & & 8 & & & & \\
\hline Public Comp. 1 & 46 & & 53 & & & & \\
\hline Ind. Comp. I & 17 & & 23 & & & & \\
\hline Education & 144 & 81.8 & 253 & $1,592-64,515$ & 13,564 & $8-938$ & 259 \\
\hline Public Research & 17 & & 48 & & & & \\
\hline Ind. Research & 7 & & 10 & & & & \\
\hline Public Doctoral & 18 & & 38 & & & & \\
\hline Ind. Doctoral & 5 & & 8 & & & & \\
\hline Public Comp. I & 66 & & 118 & & & & \\
\hline Ind. Comp. I & 31 & & 31 & & & & \\
\hline Engineering & 60 & 61.9 & 116 & $3,227-64,515$ & 20,365 & $14-1,402$ & 488 \\
\hline Public Research & 15 & & 50 & & & & \\
\hline Ind. Research & 3 & & 6 & & & & \\
\hline Public Doctoral & 11 & & 22 & & & & \\
\hline Ind. Doctoral & 3 & & 4 & & & & \\
\hline Public Comp. I & 19 & & 27 & & & & \\
\hline Ind. Comp. 1 & 9 & & 7 & & & & \\
\hline Journalism & 66 & 70.2 & 133 & $2,088-64,515$ & 22,596 & $6-400$ & 124 \\
\hline Public Research & 19 & & 58 & & & & \\
\hline Ind. Research & 4 & & 10 & & & & \\
\hline Public Doctoral & 12 & & 18 & & & & \\
\hline Ind. Doctoral & 4 & & 7 & & & & \\
\hline Public Comp. I & 20 & & 31 & & & & \\
\hline Ind. Comp. I & 7 & & 9 & & & & \\
\hline Law & 59 & 56.7 & 119 & $2,560-64,515$ & 19,767 & $19-586$ & 235 \\
\hline Public Research & 20 & & 48 & & & & \\
\hline Ind. Research & 7 & & 13 & & & & \\
\hline Public Doctoral & 13 & & 23 & & & & \\
\hline Ind. Doctoral & 2 & & 4 & & & & \\
\hline Public Comp. I & 7 & & 13 & & & & \\
\hline Ind. Comp. I & 10 & & 18 & & & & \\
\hline
\end{tabular}


TABLE 1. (Continued)

\begin{tabular}{|c|c|c|c|c|c|c|c|}
\hline \multirow{2}{*}{$\begin{array}{l}\text { Professional } \\
\text { Program and } \\
\text { Institutional } \\
\text { Type }\end{array}$} & \multirow{2}{*}{$\begin{array}{c}\text { Programs } \\
\text { Responding }\end{array}$} & \multirow{2}{*}{$\begin{array}{c}\text { Percentage } \\
\text { Response }\end{array}$} & \multirow{2}{*}{$\begin{array}{c}\text { No. of } \\
\text { Faculty } \\
\text { in } \\
\text { Analysis }\end{array}$} & \multicolumn{2}{|c|}{$\begin{array}{l}\text { Institutional } \\
\text { Enrollment }\end{array}$} & \multicolumn{2}{|c|}{$\begin{array}{c}\text { Number of } \\
\text { Annual Program } \\
\text { Graduates }\end{array}$} \\
\hline & & & & Range & Mean & Range & Mean \\
\hline Library Science & 43 & 95.6 & 103 & $2,992-64,515$ & 24,329 & $5-350$ & 62 \\
\hline Public Research & 22 & & 61 & & & & \\
\hline Ind. Research & 5 & & 11 & & & & \\
\hline Public Doctoral & 8 & & 20 & & & & \\
\hline Ind. Doctoral & 0 & & 0 & & & & \\
\hline Public Comp. I & 7 & & 8 & & & & \\
\hline Ind. Comp. I & 1 & & 3 & & & & \\
\hline Nursing & 96 & 85 & 202 & $1,477-64,515$ & 14,859 & $6-238$ & 100 \\
\hline Public Research & 13 & & 37 & & & & \\
\hline Ind. Research & 4 & & 7 & & & & \\
\hline Public Doctoral & 12 & & 30 & & & & \\
\hline Ind. Doctoral & 4 & & 12 & & & & \\
\hline Public Comp. I & 46 & & 77 & & & & \\
\hline Ind. Comp. I & 17 & & 39 & & & & \\
\hline Pharmacy & 31 & 73.8 & 40 & $5,997-42,230$ & 21,519 & $37-160$ & 97 \\
\hline Public Research & 17 & & 25 & & & & \\
\hline Ind. Research & 2 & & 0 & & & & \\
\hline Public Doctoral & 7 & & 6 & & & & \\
\hline Ind. Doctoral & 1 & & 1 & & & & \\
\hline Public Comp. I & 2 & & 6 & & & & \\
\hline Ind. Comp. I & 2 & & 2 & & & & \\
\hline Social Work & 69 & 63.9 & 129 & $1,968-64,515$ & 18,133 & $1-296$ & 57 \\
\hline Public Research & 19 & & 35 & & & & \\
\hline Ind. Research & 6 & & 4 & & & & \\
\hline Public Doctoral & 17 & & 30 & & & & \\
\hline Ind. Doctoral & 3 & & 2 & & & & \\
\hline Public Comp. I & 39 & & 43 & & & & \\
\hline Ind. Comp. I & 11 & & 15 & & & & \\
\hline
\end{tabular}

iors and structure views of the work role, it is also plausible that faculty time use could be an independent variable and faculty role view a dependent variable. Given substantial autonomy in the faculty role, however, and the fact that in many institutions only certain roles (teaching and administrative tasks) are mandatory while others (research, consulting, and independent practice) are pursued at will for intrinsic or extrinsic rewards, we used a regression model that posits faculty time use as the dependent variable and faculty role view as one of the predictors.

\section{The Dependent Variables}

The dependent variables were self-reported faculty time use in five roles. 
In responding to the survey, faculty members were asked to circle the percentage of working time (on an 11-point scale ranging from $0 \%=1$ to $100 \%=11$ ) that they were spending during the 1985 academic year in different types of faculty roles: teaching, research, professional practice, consulting, and administration.

Using the original scaled data, analysis of variance with post hoc contrasts of all pairs was used to compare the faculty reports of time usage. For ease of interpretation and comparison with other studies, however, we have also reported mean percentages of time after interpolation and minor proportional adjustments to bring total group means to $100 \%$.

\section{The Independent Variables}

\section{Fixed Personal and Institutional Variables}

As fixed variables, we entered into the regression those demographic and environmental factors already established by other studies as predictors of faculty roles. Previous researchers have linked both age and gender to faculty role performance. Specifically, research productivity has been noted to decline (either linearly or curvilinearly) with age, while women faculty are reported to teach (and prefer to teach) more than men while publishing less scholarly work. Similarly, institutional type is well established as a predictor of faculty roles; faculty members in research universities devote more time to research and less to teaching, while the reverse is true for comprehensive colleges.

Age: Reported chronological age in years.

Gender: A dummy variable ( $1=$ male, $0=$ female).

Institutional Type: Five dummy variables (public research university, independent research university, public doctoral university, independent doctoral university, public comprehensive college; Standard: private comprehensive college).

\section{Environmental Variables}

As mentioned earlier, time spent in doctoral study at a prestigious university is believed to have a strong socializing influence that leads faculty in the disciplines to internalize the research role. Similarly, a period of professional practice may provide a socializing influence for professional field faculty. Thus, we included both possession of a doctorate and an indicator of time spent in professional practice as variables which might affect faculty time use. Additionally, professional field faculty may be subject to a variety of external influences that structure their work. Since in previous analyses we found significant differences among the professional faculty groups in the 
extent of influence they believed their field exerted (Stark, Lowther, and Hagerty, 1986a), we included a measure of perceived influence as a potential predictor variable for faculty time use. In summary, three environmental variables were added to the analysis:

Possession of Doctorate: A dummy variable ( $1=$ Yes, $0=\mathrm{No})$

Practice Experience: Ratio of years of full-time professional practice to years of faculty service (correlation with age $=-.07$ ).

Professional Community Influence: A factor score measuring the extent to which the faculty member perceives that the professional community influences the educational program. The factor score was derived from responses of 2,217 administrators and faculty members in ten fields to seven items comprising a single professional community influence factor. The items included knowledge consensus and ethical code consetisus of the field, practice settings for students, accrediting rigor and enforcement, impact of publications, and alumni involvement (Stark et al., 1986b).

\section{Reinforcer Variables}

Previous investigations, particularly those attempting to identify predictors of the research role of faculty members, have considered the faculty member's own role view as a strong reinforcer of time use. Our analysis included such faculty ratings of their own roles. In each regression equation, the role most closely related to the dependent variable was used as a potential predictor. Thus, research time was regressed upon faculty members' views of the importance to them of the researcher role; consulting time on their expressed importance of the consultant role, and so on. In light of previously identified differences among professional field faculty in their degree of concern for student competence development (Stark, Lowther, and Hagerty; 1986c), we also included, as a potential predictor of faculty time use, a five-item scale representing the faculty member's "espoused ideology" toward professional education. Lastly, because it establishes group norms, discipline affiliation has been seen as a potential reinforcer. Our analysis substituted professional field for discipline and entered this variable last in the regression in order to determine if there remained field-specific variance not explained by previously entered variables.

Faculty Role View. Faculty were asked how they viewed themselves in their profession with respect to five major roles (teacher, scholar, administrator, professional practitioner, and consultant) as follows: "Please help us understand how you view yourself in your profession. Use the scales below to indicate how important each of the roles given below is to you. $(1=$ Not at All Important to 7 = Extremely Important.)" 
Professional Education Ideology. This scale summed responses to five competence statements, each of which respondents had rated on a 7-point scale. Faculty members were asked to judge the amount of emphasis that should be given to developing among entry level professional graduates each of five competences: conceptual competence, technical competence, contextual competence, professional identity, and scholarly concern for improvement of the profession. All professional educators view these outcomes as highly important (Stark et al., 1986c). Nonetheless, in previous analyses, we found that three groups of professional faculty members tended to judge their educational importance somewhat differently. Faculty members placing highest emphasis on this combination of outcomes were most frequently in nursing, social work, and education; those placing moderate emphasis were more frequently in journalism, library science, and pharmacy; and those placing lowest emphasis were in engineering, law, business, and architecture. The groups of faculty espousing highest emphasis on these educational outcomes also expressed the greatest consensus.

Professional Field Identification. Professional field was entered as nine dummy variables (Standard: master of social work program).

\section{RESULTS}

The demographic characteristics of the professional field faculty members whose responses were included in the analysis are provided first. Thereafter, the report of the results follows the three questions posed in the study objectives. First, the distributions and intercorrelations of the dependent variables, faculty time use in five academic roles, are described. Second, the distributions of the various independent variables and their intercorrelations are examined. Finally, the results of the hierarchical multiple regression are reported.

\section{Demographic Characteristics of Respondents}

Within the more extensive survey, faculty respondents were asked for demographic information including age, sex, years of faculty experience, years of experience as a full- and part-time professional practitioner, highest degree held, and faculty rank. These demographic characteristics of the analysis sample are shown in Table 2.

As shown in Table 2, faculty members teaching in the various professional fields differ on demographic variables such as age, gender, rank, and mean years of experience in both teaching and professional practice. Most of these differences are not unexpected; for example, it is well known that many education faculty members spend an extended period of time in professional 


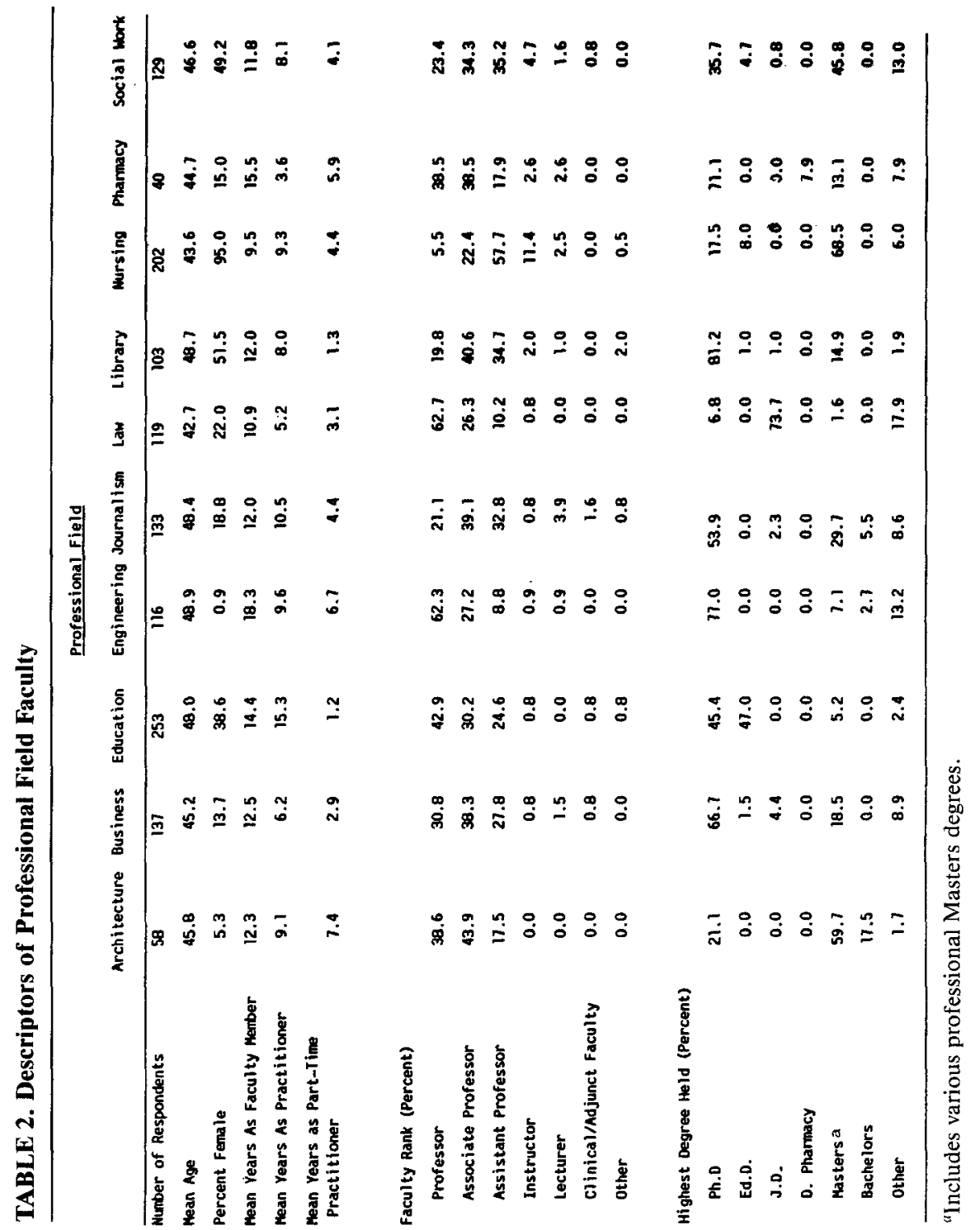


practice before entering college and university teaching, whereas law and pharmacy faculty members are less likely to do so. It is also known that architecture faculty members have opportunity to practice their profession on a part-time basis, while such possibilities for faculty members in fields such as education and library science are far more limited.

The survey was intentionally distributed to those faculty teaching in the "entry level" program; thus, it is not surprising that for law (a postbaccalaureate study), the respondents should be primarily full professors. In contrast, undergraduate teachers in architecture, nursing, and social work are likely to hold lower ranks and to hold a degree below the doctorate. These demographic differences illustrate characteristics of professional field faculties that enter importantly into the comparisons reported here.

\section{Professional Field Differences in Faculty Time Usage}

Table 3 gives the means and standard deviations (based on an 11-point scale) of faculty self-reports of time spent in various roles. Table 4 provides the same information translated to percentages. Although faculty in all professional fields reported devoting $59 \%$ or more of their total working time to teaching, there were significant differences among the ten fields. Law and pharmacy faculty reported relatively low teaching time $(59 \%$ and $60 \%$ ), while nursing, journalism, social work, and education faculty reported more $(66 \%-74 \%)$. Perhaps because they are located in a variety of institutional types, reports of teaching time by education and journalism faculty varied widely. Faculty differ even more substantially, however, in self-reports of time spent on research, ranging from $9.6 \%$ for nursing faculty to $29 \%$ for law faculty. Substantial variance in the amount of time devoted to research occurred among those faculty groups with the highest average percentages: pharmacy, business, law, library science, and engineering.

These results for teaching and research time are consistent with broad ranges of time use summarized elsewhere. Depending on type of institution, faculty have been reported to spend $33 \%-66 \%$ of their time in teaching and $9 \%-23.5 \%$ in research (Finkelstein, 1984, pp. 88-89). Since our method of sampling by program included a higher proportion of faculty teaching in programs like education, journalism, and business that are frequently located in nonresearch institutions, it is not surprising that teaching time reported by faculty members in our sample was toward the high end of previously reported ranges.

Since we restricted our analysis to those faculty members not holding any formal administrative title, it is likely that respondents reporting administrative time were performing coordinating or committee tasks typically in- 
TABLE 3. Description of Dependent Variables

\begin{tabular}{lcccccc}
\hline Dependent Variables & $N$ & Mean $^{a}$ & SD & Skewness & $F$ & $p$ \\
\hline Teaching Time $^{b}$ & 1,294 & 11.02 & 2.58 & 0.70 & 10.43 & .00 \\
Research Time & 1,294 & 2.58 & 1.55 & 1.35 & 22.41 & .00 \\
Professional Practice Time & 1,294 & 1.41 & 0.90 & 4.07 & 5.87 & .00 \\
Consulting Time & 1,294 & 1.53 & 0.78 & 3.54 & 2.58 & .01 \\
Administrative Time & 1,294 & 1.81 & 1.51 & 2.69 & 1.76 & .07 \\
\hline
\end{tabular}

"Total group descriptive statistics are given here solely for the purpose of describing the variables. No implication is intended that this sample is representative of all professional field faculty.

${ }^{b}$ Teaching time is the sum of four 7-point scales dealing with different types and levels of teaching.

cluded in faculty roles. The comparison across fields was not statistically significant at the .05 level, and less than $10 \%$ of the time of the faculty respondents in most fields is spent on such administrative tasks. This is less than the $17 \%-18 \%$ reported nationally, which presumably includes program or school level administrators (Finkelstein, 1984, pp. 88-89). Pharmacy, education, and social work faculty report the highest percentage of administrative time, while journalism, law, and library science faculty members report less.

Relative to other academic roles, professional faculty reported spending relatively little time in independent professional practice (range: $2.3 \%-9.9 \%$ ) or consulting (range: $2.5 \%-6.3 \%$ ). Although it may be assumed that independent professional practice is a compensated activity, consulting may be paid or volunteer (Boyer and Lewis, 1985). While definitions may vary, both activities may be viewed as professional work done outside the university which occupies from $4.7 \%$ to $15.3 \%$ of the working time of professional faculty members. These figures are substantially greater, however, than the 3\%-5\% of time reportedly devoted to "community service" by faculty members generally (Finkelstein, 1984, pp. 88-89). It appears that, on the whole for professional faculty, externally directed activities occupy about half as much time as research, but judging from the skew of the distribution, a much smaller proportion of the faculty are engaged in these activities than are engaged in teaching and research.

As shown in Table 5, there are significant negative correlations among time spent in teaching, research, and administration. Professional practice, teaching, and consulting activities, on the other hand, have a modest positive association. 


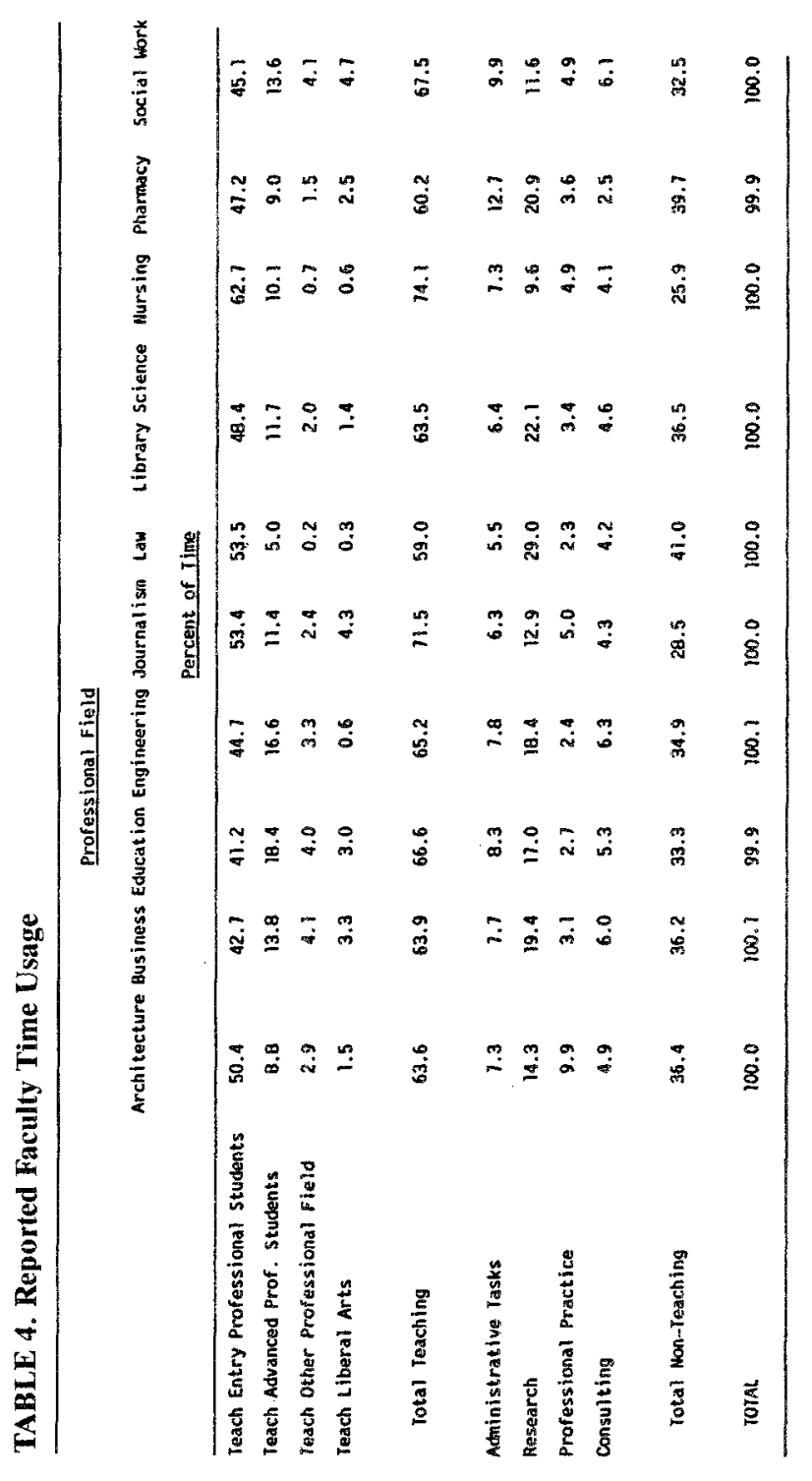


TABLE 5. Intercorrelations of Dependent Variables

\begin{tabular}{lcccc}
\hline & $\begin{array}{c}\text { Teaching } \\
\text { Time }\end{array}$ & $\begin{array}{c}\text { Research } \\
\text { Time }\end{array}$ & $\begin{array}{c}\text { Practice } \\
\text { Time }\end{array}$ & $\begin{array}{c}\text { Consulting } \\
\text { Time }\end{array}$ \\
\hline Teaching Time & - & & & \\
Research Time & $-.32^{*}$ & - & & \\
Professional Practice Time & $.07^{*}$ & -.05 & - & - \\
Consulting Time & -.01 & .04 & $.18^{*}$ & - \\
Administrative Time & $-.37^{*}$ & $-.17^{*}$ & -.03 & -0.05 \\
\hline
\end{tabular}

${ }^{*} p<.05$.

\section{Descriptions and Interrelationships of the Predictor Variables}

\section{Demographic Variables}

The distributions of faculty respondents with respect to gender, institutional affiliation, years of faculty service, age, and years of professional practice experience were described for each separate professional field in Table 2. Table 6 describes, for the entire sample, those variables used as predictors. These statistics are provided to enable the reader to understand the nature of the variable distributions rather than to imply any characteristics of professional field faculty generally. With respect to their view of their own role, $85 \%$ or more of faculty in every field said that their teaching role was "extremely important" or "very important." Education faculty members were most likely to rate the teaching role as extremely important. There was greater variance among faculty members in business than in the other fields.

In contrast to teaching, considerable diversity of role view both within and across fields was reported on the research role. Law and library science faculty felt the research role was most important. To illustrate, over $50 \%$ of law and library science faculty viewed the research role as very or extremely important, while only $30 \%$ of the education and social work faculty did so. The greatest within-field diversity regarding research occurred in architecture and journalism $(S D>2.00)$.

Diversity within and among fields was also expressed with regard to seeing oneself as a professional practitioner. More than $60 \%$ of education faculty members rated this role as very or extremely important, while less than $20 \%$ of law and business faculty members did so.

In general, the administrative and consulting roles were not very important to professional field faculty members. No more than $20 \%$ of the respondents in any group of professional faculty reported that these roles were very important or extremely important. Education, nursing, social work, pharmacy, and library science faculty viewed administration as more important roles for them than did faculty in other fields, whereas law and library science were notable for placing least importance on the consulting role. 
TABLE 6. Description of Independent Variables

\begin{tabular}{|c|c|c|c|c|c|}
\hline Independent Variables & $N$ & Mean $^{a}$ & SD & Skewness & $\begin{array}{l}\text { Percentage } \\
\text { of Sample }\end{array}$ \\
\hline Age & 1,262 & 46.38 & 9.39 & .17 & \\
\hline \multicolumn{6}{|l|}{ Perceived Professional } \\
\hline Community Influence & 1,243 & 0.00 & $0.89^{b}$ & -0.48 & \\
\hline \multicolumn{6}{|l|}{ Ratio of Professional } \\
\hline \multicolumn{6}{|l|}{ Practitioner Service to } \\
\hline Faculty Service & 1,294 & 1.33 & 2.49 & 7.26 & \\
\hline \multicolumn{6}{|l|}{ Professional Education } \\
\hline Ideology & 1,288 & 29.89 & 3.71 & -0.74 & \\
\hline Teacher Role View & 1,277 & 6.55 & 0.82 & -2.30 & \\
\hline Scholar Role View & 1,261 & 4.62 & 1.81 & -0.30 & \\
\hline Practitioner Role View & 1,221 & 4.40 & 2.03 & -0.29 & \\
\hline Consultant Role View & 1,204 & 3.37 & 1.81 & 0.24 & \\
\hline Administrator Role View & 1,207 & 2.65 & 1.78 & 0.83 & \\
\hline Public Research University & 416 & & & & 32.1 \\
\hline \multicolumn{6}{|l|}{ Independent Research } \\
\hline University & 75 & & & & $5.8^{c}$ \\
\hline Public Doctoral University & 212 & & & & 16.4 \\
\hline \multicolumn{6}{|l|}{ Independent Doctoral } \\
\hline University & 48 & & & & $3.7 c$ \\
\hline Public Comprehensive College & 385 & & & & 30.1 \\
\hline \multicolumn{6}{|l|}{ Independent Comprehensive } \\
\hline College & 154 & & & & 11.9 \\
\hline Possess Doctorate & 916 & & & & 70.8 \\
\hline Male Faculty Members & 805 & & & & 62.2 \\
\hline
\end{tabular}

${ }^{a}$ Total group descriptive statistics are given here solely for the purpose of describing the variables. No implication is intended that this sample is representative of all professional field faculty.

${ }^{b}$ Variable was standardized on broader sample.

'Sampled programs are less frequently found in independent research and doctoral universities.

Once again, it should be noted that this was a sample of teaching faculty; those faculty members who had already accepted full- or part-time administrative roles were excluded from the analysis.

\section{Correlations Among the Independent Variables}

The intercorrelations among the independent variables shown in Table 7 are difficult to interpret because of simultaneous variation of numerous faculty views and characteristics. Nonetheless, in examining correlations which take into account only pairs of variables, two general patterns suggest 


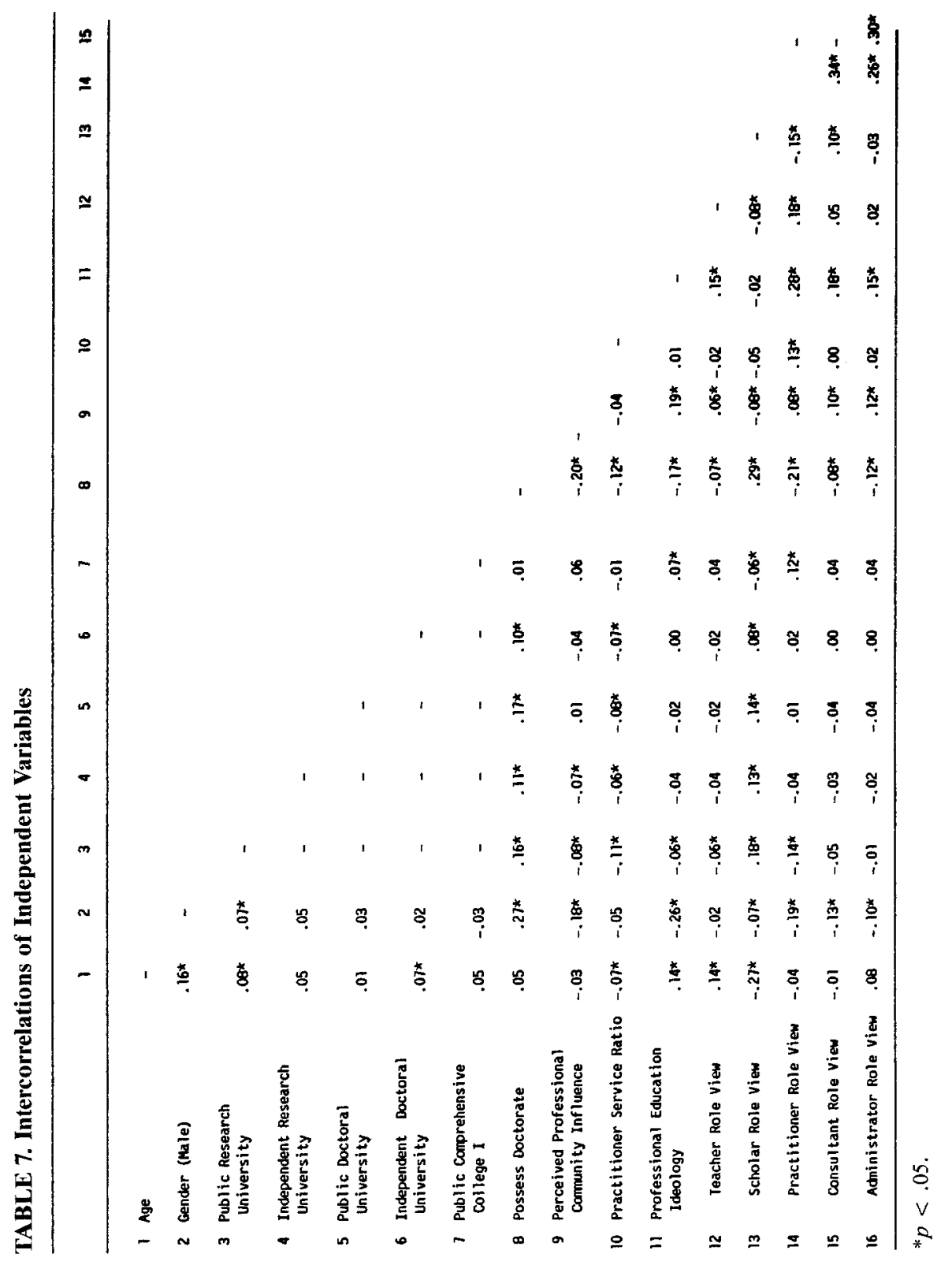


themselves: a teacher/practitioner/consultant orientation and a scholar/ nonteacher/nonpractitioner orientation.

Positive correlations occur among the responses of faculty who view the professional community as influential, have spent time as a practitioner as well as a teacher, see themselves in the role of professional practitioner/ teacher/consultant, and espouse a competence-based philosophy for professional students. This pattern of interrelationships, apparently based on a professional practice orientation, is negatively related to viewing oneself as a scholar. Faculty members with this orientation appear most likely to be located in colleges and universities not usually classified as research or doctoral institutions. In contrast, faculty members in research universities and independent doctoral universities were more likely to possess doctorates and view themselves as researchers, least likely to view themselves as professional practitioners, and were more frequently male than female.

\section{Correlations Among the Dependent and Predictor Variables}

The bivariate correlations between the dependent and predictor variables (shown in Table 8) appear to support some of the previous findings regarding faculty roles. For example, self-reported research time is negatively correlated with age; more time is devoted to teaching and less to research in primarily teaching colleges (while the reverse is true for research institutions); and there are substantial correlations between the importance faculty members attach to roles and the way they spend their time. Male faculty members are slightly more likely to spend time in research and administration than are females, but the relationship between gender and teaching time is not significant.

A contradiction of a previous assertion may also be noted. It appears that among professional faculty, those in research universities do not spend more time in consulting than do faculty in nonresearch colleges (Fox, 1985).

Significant relationships that have not previously been reported but which support consideration of new variables important in the study of professional field faculty also appear. Prior service as a practitioner, viewing oneself as a practitioner, and espousing a competence-based ideology of professional education are more positively associated with spending time in teaching than in research.

\section{Predictors of Faculty Time Usage}

The results of the hierarchical regression analyses are shown in Tables 9 and 10. As is illustrated in Table 9, in all roles except teaching, the greatest increase in prediction of faculty time use was obtained when those variables 
TABLE 8. Bivariate Correlations Between Dependent and Independent Variables

\begin{tabular}{|c|c|c|c|c|c|}
\hline \multirow[b]{2}{*}{ Independent Variables } & \multicolumn{5}{|c|}{ Dependent Variables } \\
\hline & $\begin{array}{l}\text { Teaching } \\
\text { Time }\end{array}$ & $\begin{array}{l}\text { Research } \\
\text { Time }\end{array}$ & $\begin{array}{l}\text { Practice } \\
\text { Time }\end{array}$ & $\begin{array}{l}\text { Consulting } \\
\text { Time }\end{array}$ & $\begin{array}{c}\text { Admini- } \\
\text { strative } \\
\text { Time }\end{array}$ \\
\hline Age & $.09^{*}$ & $-.22 *$ & -.04 & .03 & $.09 *$ \\
\hline Possess Doctorate & $-.11^{*}$ & $.33 *$ & $-.18 *$ & .03 & -.06 \\
\hline Gender (Male) & -.04 & $.11^{*}$ & -.05 & .04 & .01 \\
\hline $\begin{array}{l}\text { Institutional Type } \\
\text { Public Research University }\end{array}$ & $-.17^{*}$ & $.23^{*}$ & $-.10^{*}$ & -.02 & .00 \\
\hline $\begin{array}{l}\text { Independent Research } \\
\text { University }\end{array}$ & $-.07^{*}$ & $.13^{*}$ & $-.09 *$ & .02 & .00 \\
\hline Public Doctoral University & $-.10^{*}$ & $.11^{*}$ & -.05 & .00 & -.02 \\
\hline $\begin{array}{l}\text { Independent Doctoral } \\
\text { University }\end{array}$ & -.04 & $.09 *$ & $-.06^{*}$ & .04 & -.01 \\
\hline $\begin{array}{l}\text { Public Comprehensive } \\
\text { College I }\end{array}$ & $.13^{*}$ & $-.08^{*}$ & -.01 & .03 & -.03 \\
\hline $\begin{array}{l}\text { Perceived Professional } \\
\text { Community Influence }\end{array}$ & -.02 & $-.14^{*}$ & .03 & -.01 & $.10^{*}$ \\
\hline Practitioner Service Ratio & $.13^{*}$ & $-.06^{*}$ & .01 & .00 & -.05 \\
\hline Professional Education Ideology & $.07^{*}$ & $-.16^{*}$ & .00 & .01 & $.08 *$ \\
\hline $\begin{array}{l}\text { Self Role View } \\
\text { Teacher }\end{array}$ & $.16^{*}$ & $-.16^{*}$ & $-.06^{*}$ & .00 & $-.06^{*}$ \\
\hline Scholar & $-.26^{*}$ & $.57 *$ & $-.11^{*}$ & .01 & $-.11^{*}$ \\
\hline Practitioner & $.18^{*}$ & $-.33^{*}$ & $.24^{*}$ & $.08 *$ & .03 \\
\hline Consultant & -.04 & $-.07 *$ & $.08 *$ & $.40^{*}$ & .02 \\
\hline Administrator & $-.12 *$ & $-.22^{*}$ & -.02 & .02 & $.51 *$ \\
\hline
\end{tabular}

${ }^{*} p<.05$.

referred to by Fox as "reinforcer" variables were added to the regression equation. More specifically, the faculty members' views of their own most important role are significantly related to all of the possible ways they spend their time.

As shown in Table 10 for both teaching and research, but not for other time uses, the type of institution in which the faculty members are employed (which entered the regression as a "fixed" variable) contributed modestly to the regression equation. In contrast, when all of the variables selected as potentially related to use of faculty time are taken into account, gender appears to have no significance as a predictor.

The greatest amount of the variance in time use $(42.8 \%)$ was predicted for 


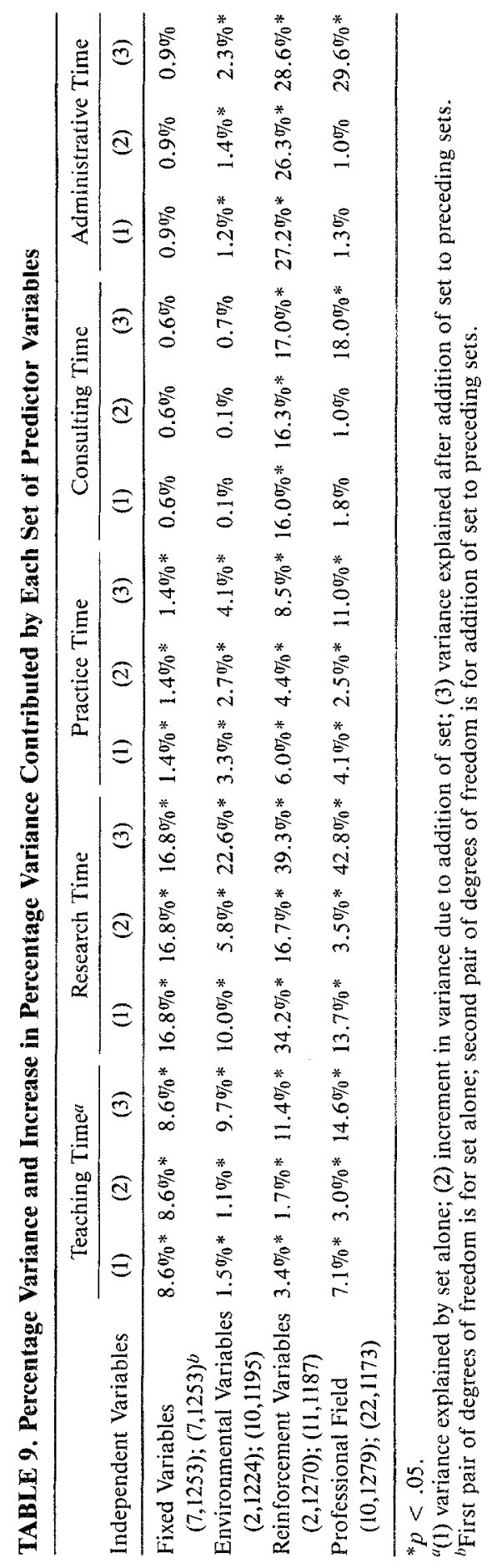


TABLE 10. Statistically Significant Predictors of Time Use with Initial Setwise Entrance of Fixed Variables Followed by Stepwise Entrance of Other Variables

\begin{tabular}{|c|c|c|c|c|c|}
\hline \multirow[b]{2}{*}{ Independent Variables } & \multicolumn{5}{|c|}{ Dependent Variables } \\
\hline & $\begin{array}{l}\text { Teaching } \\
\text { Time }\end{array}$ & $\begin{array}{l}\text { Research } \\
\text { Time }\end{array}$ & $\begin{array}{l}\text { Practice } \\
\text { Time }\end{array}$ & $\begin{array}{l}\text { Consulting } \\
\text { Time }\end{array}$ & $\begin{array}{c}\text { Admini- } \\
\text { strative } \\
\text { Time }\end{array}$ \\
\hline \multicolumn{6}{|l|}{ Fixed Variables } \\
\hline $\begin{array}{l}\text { Age } \\
\text { Gender (Male) } \\
\text { Institutional Type }\end{array}$ & .07 & -.10 & & & .06 \\
\hline $\begin{array}{l}\text { Public Research } \\
\text { Independent Research }\end{array}$ & -.14 & .11 & & & \\
\hline $\begin{array}{l}\text { Public Doctoral } \\
\text { Independent Doctoral } \\
\text { Public Comprehensive }\end{array}$ & -.08 & & & & . \\
\hline College I & .19 & -.08 & & & -.07 \\
\hline \multicolumn{6}{|l|}{ Environmental Variables } \\
\hline $\begin{array}{l}\text { Perceived Professional } \\
\text { Community Influence }\end{array}$ & & & & & .06 \\
\hline Practitioner Service Ratio & .06 & & & & \\
\hline Possess Doctorate & & .06 & & & -.05 \\
\hline \multicolumn{6}{|l|}{ Reinforcement Variables } \\
\hline $\begin{array}{l}\text { Professional Education } \\
\text { Ideology }\end{array}$ & & & -.08 & & \\
\hline Self Role View & .14 & .46 & .23 & .42 & .52 \\
\hline \multicolumn{6}{|l|}{ Professional Field } \\
\hline Architecture & & -.09 & .16 & & \\
\hline Business & -.06 & .11 & & & \\
\hline Education & & -.08 & -.09 & & \\
\hline Engineering & & & -.08 & & \\
\hline Journalism & .10 & & & & \\
\hline Law & -.12 & .12 & & & \\
\hline Library Science & & & & & \\
\hline Nursing & .13 & -.10 & & & -.11 \\
\hline Pharmacy & & & & & \\
\hline Social Work (BSW) & & & & & \\
\hline \multicolumn{6}{|l|}{ Percentage of Variance } \\
\hline Explained by Fixed Variables & $8.6 \%$ & $16.8 \%$ & 1.4 & $0.6 \%$ & $0.9 \%$ \\
\hline Total Percentage of Variance & & & & & \\
\hline Explained & $14.6 \%$ & $42.8 \%$ & $11.0 \%$ & $18.0 \%$ & $29.6 \%$ \\
\hline Overall $F$ Ratio & $9.15^{*}$ & $39.33 *$ & $6.31^{*}$ & $11.01^{*}$ & $21.11^{*}$ \\
\hline Degrees of Freedom & 22,1173 & 22,1157 & 22,1120 & 21,1103 & 22,1105 \\
\hline
\end{tabular}

${ }^{*} p<.05$. 
time devoted to research. The personal view faculty members held of the research role as important explained the greatest portion of the variance in use of time for research (beta $=.46$ ). Age, institutional type, and possession of the doctorate also contributed significantly to the regression equation; faculty in public research universities are more likely to use time for research (beta $=.11$ ) than those in public comprehensive colleges (beta $=-.08$ ). When other variables are held constant, time spent as a practitioner, views of the professional community as influential, and one's espoused ideology of professional education are not significant predictors of use of time for research. After all other variables such as age, gender, institutional type, and practitioner experience are taken into account, however, some professional fields still seem to influence use of time for research. Specifically, business administration and law could be said to have a positive climate for spending time in research, while architecture, education, and nursing apparently constitute a negative climate.

Despite the fact that faculty members holding formal administrative titles were excluded from the analysis, the second best prediction of time use was obtained for administration (29.6\% of the variance predicted). Again, one's own role view is the most extensive predictor of time use (beta $=.52$ ). Years spent as a professional practitioner, working in a comprehensive college, and being affiliated with nursing are negative predictors for using time for administrative tasks.

Use of time for consulting was predicted only modestly by the included variables $(18.0 \%)$, and the only significant predictor was a faculty member's view of the consulting role as important (beta $=.42$ ).

With respect to predictors of the use of time for teaching, fixed characteristics such as age and institutional type play a significant part in prediction. Use of time for teaching is more likely for faculty members in the public comprehensive college than in the public research university. Teaching time is also increased for those faculty members who have substantial professional practice experience. Self role view is a significant predictor of time use, but its contribution to the regression equation is weaker than for other uses of time. Finally, even after other variables are taken into account, law and business faculty appear to spend least time at teaching, while journalism and nursing faculty seem likely to spend comparatively more. The amount of variance in teaching time that was explained by the selected variables was a modest $14.6 \%$

Finally, only $11 \%$ of the variance in the use of time for independent professional practice is explained. The strongest predictors are faculty members' view of themselves as practitioners, eschewing a competence-based ideology of education, and teaching in an architecture program. As fields, education and engineering appear to provide a negative climate for independent professional practice. 


\section{CONCLUSIONS}

The questions posed in this study concerned (1) whether differences in time use varied among faculty in ten different professional fields; (2) whether correlation patterns suggested that factors different from those suggested by previous research could predict time use among professional field faculty; and (3) whether, in a multivariate analysis, predictors of time use unique to professional field faculty or to specific professional fields would be identified.

With respect to the first study question, significant differences in time use among the professional fields were identified for all roles except administration. The differences among fields were greatest for time spent in research.

Bivariate correlations indicated that variables such as age, institutional type, and gender that have been reported as related to faculty time use generally and/or scholarly productivity may also be important for professional field faculty. However, correlation patterns obtained among the independent and dependent variables also suggested that the work time of professional faculty might be based on different considerations than for disciplinary faculty. Particularly, the correlation patterns suggested that a set of variables unique to professional field faculty members, including professional practice experience and an espoused ideology of professional education, might be associated with spending time in teaching and/or consulting.

In answering the third study question, a hierarchical multiple regression allowed refinement and further understanding of these patterns. For professional field faculty, variations in use of time for research were predicted most fully by the included variables. In addition to possessing a doctorate, faculty role view and institutional type, both of which were viewed as "reinforcers" of the research role by Fox, are important predictors of research time for professional faculty as they are for faculty in the disciplines. Neither gender nor variables specific to being in a professional program appear to have much relationship to the time spent in research. Once other variables had entered the equation, a bit of additional variance in research time was attributed to specific professional fields.

As in prediction of research time, the faculty members' role view made the most important contribution to prediction of time use in administration and consulting. Time spent in professional practice was modestly associated with viewing oneself as a practitioner. As for research, in specific fields, some unidentified factors appear to be of minor significance in supporting or inhibiting the use of faculty time use for administration and consulting.

Although only a modest amount of the variance in the use of time for teaching was explained by the included variables, in this faculty role the 
special characteristics attributed to professional faculty do appear to contribute to time differences. In addition to age and institutional type, which have been previously related to emphasis on teaching for disciplinary faculty, length of professional experience was a predictor.

\section{DISCUSSION}

This exploratory study examined various factors that might cause time use of professional education faculty members to differ from that of disciplinebased faculty. Strengths of the study were as follows: (1) it included a large national sample of professional field faculty drawn from varied institutional settings; (2) it considered five faculty roles; (3) it included a broad group of faculty members rather than merely high and low publishers; (4) it excluded faculty members who are primarily administrators; and (5) it used a multivariate analysis, which allowed a variety of potential determinants of faculty time use to be considered simultaneously. Important limitations of the study are that (1) dependent variables were self-reports of faculty time use rather than independent criteria of faculty productivity in the five roles, and (2) the sample taken from a broader research project was representative of programs rather than of professional faculty generally.

The results provide limited support for the speculation that strong external associations with practitioners outside the university influence time use of professional faculty. In fact, since the strongest predictor of faculty time use is the role that faculty members view as important, the results seem to support another researcher's conclusion "that faculty basically do what they want and their personal and professional goals become the operational goals of the university" (Borland, cited in Finkelstein, 1984, p. 93).

In particular, our results support the conclusion of others that the strongest predictors of research productivity may be a preference for research (Blackburn, Behymer, and Hall, 1978; Creswell, 1985, p. 41). The predictors of time spent in research discovered in our data also confirm findings that (1) both a view of research as an important role and the time spent in research decline with age (Finkelstein, 1984, p. 137), and (2) faculty members working in institutions whose missions are strongly oriented to research or teaching spend their time in ways that are consistent with the institutional mission. Contrary to previous research findings, however (Finkelstein, 1984, p. 190), no evidence was found that faculty time use differs according to the gender of the faculty member when a variety of factors such as age, type of institution, and possession of the doctorate are taken into account simultaneously. Quite possibly, earlier reports that women spend less time in research have been confounded by other variables. For example, about $25 \%$ of professional field faculty do not possess doctoral degrees, and these faculty 
members tend to be most frequently found in the heavily female fields of nursing, education, social work, and library science. When possession of the doctorate is controlled, observed gender differences in research orientation among the professional fields may no longer be significant.

Although there were differences among professional fields, respondents in all fields reported that more than half of their time is devoted to teaching. Beyond the anticipated effects of age and institutional type, professional orientation of faculty plays a part in determining teaching time. Specifically, faculty members who have spent time as professional practitioners tend to spend more time in teaching even when possession of the doctorate is taken into account. Finally, the faculty member's view of the importance of teaching is a much weaker predictor of time spent in teaching than is the importance faculty attach to other roles. This may indicate that, relative to other roles, teaching is most often viewed as an obligation. Such an interpretation is constrained, of course, by the fact that teaching is most likely to be the role to which faculty are assigned rather than one they self-select. Our data provided no support for the assertion that, with many other variables taken into account, women teach (or prefer to teach) more than men.

Concern has been expressed among legislators and the public about faculty members who carry on extensive professional practice or consulting. While professional faculty members appear to spend slightly more time in a combination of practice or consulting than discipline-based faculty, our data are consistent with other reports (Boyer and Lewis, 1985) that indicate the amount of time spent in such activities is less than $20 \%$ of the total working time. When faculty members do spend considerable time, it is likely they consider consulting or practice roles important rather than because any other demographic or environmental factor or reinforcing influence encourages them to do so. Additionally, in some schools of architecture (and medicine and dentistry, which we did not examine), continuation of independent practice may be prearranged with the university. Again, after controlling for other variables, no evidence was found that women were less likely to engage in consulting than men (Finkelstein, 1984, p. 200).

Although professional orientations served as significant predictors of faculty time use only for the teaching role, this should not obscure the fact that there is considerable variability among the professional fields in other aspects of faculty time use and its correlates. While multivariate analyses use statistical controls to sort out important predictive factors, such controls do not exist in the real world. The fact remains that in schools of nursing, teaching loads tend to be comparatively heavy; in schools of education, group norms are not particularly supportive of research; but in contrast to departments of business and law, they are strongly supportive of teaching.

Each professional field may have its own "group climate," which helps to 
reinforce certain faculty roles. These climates may depend upon gender, age, and other variables that were controlled in our analysis, as well as on variables which remain influential after controlling for demographic factors. In predicting research time, for example, professional field alone accounted for about $13 \%$ of the variance, and while our data do not provide interpretations, some specific field influences remained even after controlling for institutional type and other factors (Finkelstein, 1984, p. 95).

As those with backgrounds in professional fields comprise an increasingly larger part of college and university faculties, it appears that, within limitations placed by their own backgrounds, they have adopted institutional and colleague norms with respect to research roles. Since reinforcers for the research role are apparently very strong, little modification of previous findings concerning faculty scholarly roles seems needed. Productive future research, however, could explore more fully the relationship between professional practice orientations and the teaching role which has only surfaced in the study reported here.

Acknowledgment. The authors express appreciation to Carol Freedman-Doane and Peter D. Rush for assistance with the survey on which this article draws.

\section{NOTES}

1. Expected enrollment decline was included as a stratifier for reasons germane to the purposes of the broader study for which the data were collected.

\section{REFERENCES}

Blackburn, Robert T. Behymer, Charles E., and Hall, David E. (1978). Research note: correlates of faculty publications. Sociology of Education 51(2): 132-141.

Boyer, Carol M., and Lewis, Darrell R. (1985). And on the Seventh Day: Faculty Consulting and Supplemental Income. ASHE/ERIC Higher Education Reports, No. 3. Washington: The Association for the Study of Higher Education.

Creswell, John W. (1985). Faculty Research Performance: Lessons from the Sciences and Social Sciences. ASHE/ERIC Higher Education Reports, No. 4. Washington: The Association for the Study of Higher Education.

Doyle, Kenneth O., Jr. (1983). Evaluating Teaching. Lexington, Mass.: D. C. Heath.

Finkelstein, Martin J. (1984). The American Academic Profession: A Synthesis of Social Scientific Inquiry Since World War II. Columbus: Ohio State University Press.

Fox, Mary Frank. (1985). Publication, performance and reward in science and scholarship. In John C. Smart (ed.), Higher Education: Handbook of Theory and Research, Vol. I. New York: Agathon Press.

Lewis, Darrell R., and Becker, William E. Jr. (eds.). (1979). Academic Rewards in Higher Education. Cambridge, Mass.: Ballinger. 
Light, Donald, Marsden, L.R., And Corl, T.C. (1972). The Impact of the Academic Revolution on Faculty Careers. ERIC/AAHE Research Reports, No. 10. Washington: American Association for Higher Education.

Stark, J. S., Lowther, M. A., and Hagerty, B. M. K. (1986a). Faculty perceptions of professional preparation environments: a test of a conceptual framework for studying preservice professional programs. Paper presented at the Association for Institutional Research Forum, Orlando, Fla., June 22-25.

Stark, J. S., Lowther, M. A., and Hagerty, B. M. K. (1986b). Technical Report of a Survey of Professional Educators in Ten Fields. Ann Arbor: The University of Michigan Center for the Study of Higher and Postsecondary Education. Unpublished.

Stark, J. S., Lowther, M. A., and Hagerty, B. M. K. (1986c). Faculty priorities for student competence in ten fields of professional study. Paper presented at the Association for the Study of Higher Education. San Antonio, Texas, February 22, 1986.

Stark, J. S., Lowther, M. A., Hagerty, B. M. K., and Orczyk, C. (1986). A conceptual framework for the study of preservice professional programs in colleges and universities. Journal of Higher Education 57(3): 231-258.

Tuckman, Howard P., and Hagemann, Robert P. (1976). An analysis of the reward structure in two disciplines. Journal of Higher Education 47(4): 447-464.

Yuker, Harold E. (1984). Faculty Workload: Research, Theory and Interpretation. ASHE/ERIC Higher Education Research Reports, No. 10. Washington: The Association for the Study of Higher Education.

Received March 12, 1986 